\title{
Theology of Music and Hindu Religion: From Divine Origins to Classical Songs
}

\author{
Guy L. Beck
}

check for

updates

Citation: Beck, Guy L. 2021. Theology of Music and Hindu Religion: From Divine Origins to Classical Songs. Religions 12: 663 https://doi.org/10.3390/rel12080663

Academic Editor: Joseph Rivera

Received: 31 July 2021

Accepted: 16 August 2021

Published: 19 August 2021

Publisher's Note: MDPI stays neutral with regard to jurisdictional claims in published maps and institutional affiliations.

Copyright: (C) 2021 by the author. Licensee MDPI, Basel, Switzerland This article is an open access article distributed under the terms and conditions of the Creative Commons Attribution (CC BY) license (https:// creativecommons.org/licenses/by/ $4.0 /)$.
Department of Religious Studies, Loyola University New Orleans, 6363 St. Charles Avenue, Campus Box 81 New Orleans, LA 70118, USA; glbeck@loyno.edu

Abstract: As a subfield in the study of religion and music, the theology of music is generally understood in Western terms. Yet to fully encompass the rich heritage of music in world religions, the theology of music must welcome non-Western traditions. After introducing ancient Greek and Biblical narratives regarding the origins of music, including metaphysical concepts, narratives of music as Divine Gift, musical angels, and the sacred origin of the notes and scales, this article explores music in Hindu religion through the lens of theology. We find that Indian music is also 'given by the gods' (i.e., Brahmā, Vishnu, and Śiva), associated with 'musical angels,' and originally formed from metaphysical principles (i.e., OM and the concept of Nāda-Brahman). What is demonstrated here, representing a long continuity, is how these same ideas are viable in the performance of Indian classical music today. Citing examples of compositions of Dhrupad and Khayal from the standard repertoire, this article reveals how modern-day classical songs contain references to sacred sound principles and the divine origins of music, both in their lyrics and in the unfoldment of musical notes (Svaras) and melodic patterns (Rāgas).

Keywords: theology; sacred music; musicology; Hinduism

"We worship Nāda-Brahman, that incomparable bliss which is immanent in all the creatures as intelligence and is manifest in the phenomenon of this universe. Indeed, through the worship of Nāda are worshipped gods Brahmā, Vishnu, and Śiva, since essentially they are one with it ... Nāda is differentiated into twenty-two grades which, because of their audibility, are known as Śrutis. From the Śrutis arise the seven musical notes."

Sañgīta Ratnākara of Śārngadeva (13th century India)

"Music is the donum Dei, the gift from God, and therefore is only secondarily a human art or science."

\section{Martin Luther (16th century Germany)}

In a prior article in Religions, "Sacred Music and Hindu Religious Experience: From Ancient Roots to the Modern Classical Tradition" (Beck 2019), this author focused on the history of music in Hindu religious experience and worship as manifest in classical songs containing references to devotion to deities like Krishna, Siva, and the Goddess. In the present article, the emphasis is on theology of music and Hindu religion: divine origins including music as Divine Gift, musical angels, sound and sacrifice, music as emanating from metaphysical principles, and the manifestation of these ideas within the lyrics of classical songs. In several ways, this article exemplifies the theme of this Special Issue, "Tuning in the Sacred," by discussing the Greek system of harmony that has impacted sacred music in at least three religions, and then juxtaposing this with the Hindu tradition of musical notes emanating from the sacred syllable OM, first as part of sacrificial ritual and then as classical and devotional music.

There are many fruitful and interesting reasons to inquire about the sacred ancestry of classical music, whether in the Western context or the Indian tradition. Behind the great 
Romantic composers of Europe, for example, lies a long tradition of sacred music originating in ancient Greece and in Biblical history. Although a somewhat specialized subject, scholars have written about both theology and music as a backdrop to the emergence of ecclesiastical and liturgical application of chant and musical instrumentation. Yet the inclusion of music in religious studies as well as in theology has only recently begun to rise to a significant level. Further discussion of the issues and debates regarding the study of religion and music are taken up as part of a new field called Musicology of Religion, outlined by this author (see Beck 2021).

As a general field of study, theology takes the reality of the sacred and God as axiomatic and not as human projection, such as found, for example, in the social sciences. Geoffrey Wainwright, in Doxology: The Praise of God in Worship, Doctrine and Life. A Systematic Theology (Wainwright 1980, p. 1) has defined theology: "Theology is intellectual reflection on all the dealings between God and humanity." In terms of theology and music, Richard Viladesau underscores the importance of the visual and performing arts in Theology and the Arts: Encountering God through Music, Art, and Rhetoric (Viladesau 2000). Building upon the categories originally presented in 1923 by Rudolf Otto in The Idea of the Holy, Viladesau (2000, p. 41) sets the parameters for a cross-cultural theology of music based upon Otto's concept of the numinous: "There is an underlying implicit or transcendental dimension of religious experience. Its object-the mysterium tremendum et fascinans, the numinous-would then be ontologically identical with the ultimate object of aesthetic or moral or intellectual experience; it would never be experienced simply in itself as a categorical object but would always be 'co-experienced' as the dimension of mystery implicit in all human knowing and loving; and it would ground the analogies that are in fact found in the human reaction to the beautiful, the good, the true, and the holy. In this perspective, the ultimate reason for music's ability to mediate the spiritual is not merely that it echoes emotions that are felt in religious experience, but also and more profoundly that its object is the beautiful, which itself is godly and thus leads toward God." As a Protestant theologian and pioneer in establishing religious studies, Rudolf Otto (1958, p. 190) fully understood the importance of sound and its fundamental connection with the numinous or the holy: "Feelings and emotions, as states of mental tension, find their natural relaxation in uttered sounds. It is evident that the numinous feeling also, in its first outbreak in consciousness, must have found sounds for its expression, and at first inarticulate sounds rather than words."

Catholic theologian Joseph Gelineau (1989, p. 137) also recognized the universal dimension of sound as resonating with religious revelation and sacrificial acts reaching back to the beginning of time, including both the Biblical revelation and ancient Indian religion: "Sound - voice or music — constitutes a sacred link with the transcendent being. The religious significance of the sacrifice of sound is global, at once evocation and adoration, invocation and praise, from the syllable ' $\mathrm{OM}^{\prime}$ ' which contains within it all the acoustic powers, to the vocal expression of a Kyrie or an Alleluia. The sacrifice of sound is at the root of all cults containing song and music. In the Biblical revelation, it constitutes a force which carries us from blood sacrifices to the pure sacrifice of the lips, already present in the prophet Hosea (Hos 14: 2 [chap. 14., v. 2]) and taken up again by the Epistle to the Hebrews (Heb 13: 15 [chap. 13., v. 15]). It will culminate in the sacrifice of thanksgiving (sacrificium laudis) from Psalm 50, vv. 14 and 23, to the Christian Eucharist where it becomes the sacrament of spiritual sacrifice."

Sages, spiritual masters, and religious communities around the world seem to have known and understood the spiritual significance of sound for thousands of years, as evident in ancient texts and inscriptions. Many examples could be discussed in this respect, for example ancient China or the civilizations of the Middle East, but our focus begins with ancient Vedic India which revered the element of sacred sound so strongly that it believed the universe to have been created through the agency of sound, especially the syllable OM. This article examines these notions of Hindu sacred sound and how they are reiterated within the lyrics of current classical songs in the genres of Dhrupad and Khayal. However, 
to provide a comparative context for this topic, we begin with a general discussion of theology of music, including music as Divine Gift, musical angels, and the sacred origin of musical systems.

\section{Theology of Music}

When Alfred Pike wrote $A$ Theology of Music as his doctoral thesis in music at the Philadelphia Conservatory of Music in 1953, he was noted as one of the first modern scholars to present a coherent 'theology of music.' In this work, Pike (1953, p. 80) describes how music is embedded in ancient beliefs of divine origin and in practices of ritual and worship: "Archaeology has unearthed evidence that earliest man used music in religious ritual and worship. Our First Parents, and their descendants, used some form of song in their praise of God, and from this it can be inferred that God approved of this method of worship. The Old Testament states that the Creator infused all natural knowledge (including knowledge of artistic principles), into the progenitors of the human race at the time of creation. If this were true, music pre-existed the human race, and is divine. It is only down through the years that music finally became independent of religion, and developed into pure art, but the underlying feeling of its divine origin is still present in all great music worthy of the heritage."

The concept of music as Divine Gift or 'Gift of the Gods' is one of the near universal features of the theology of music. In some form or another, this idea is found in most ancient religions, according to Johannes Quasten (1983, p. 1), who explains how music was widely viewed as a gift of the gods to be performed in order to please and supplicate them: "The legends and myths of nearly all pagan peoples have sought to explain the elaborate use of music in their worship by indicating that the art of music was a gift of the gods to men ... Music is pleasing to the gods, for if it were not pleasing to the gods, then the public games which are intended to placate the gods would not have been instituted; the flutist would not attend prayers of supplication offered in sacred shrines." There are countless examples in support of the role of music in petitioning and worshipping a variety of gods and deities. For example, William Edgar (1986, pp. 24-25) briefly narrated the divine origin of music and musical instruments according to Greek sacred lore: "The Greeks, who gave us the word itself [music], have a myth about the origins of music which attributes it to the gods. Apollo's young brother Hermes had stolen some oxen from him, and he used the guts of the animals to make strings. Tying them to the two ends of a turtle shell, he gave us a primeval lyre. He appeased his brother's anger by letting him use it, and he played it with great skill. Thus, the gods are directly involved in giving us instruments. It was the same for the aulos, a kind of pipe which is found in Asia Minor. This instrument was championed by the Phrygian Olympus, and sometimes the two instruments were used as rivals. Great contests between the gods were established, and judgments were meted out for the lesser musicians." Similar scenarios of Divine Gift and the role of music in pleasing the gods are found in the Hindu tradition, as will be described.

Beside narratives of the gods, the Greeks made an enormous contribution to music theory and its link to the cosmos in the figure of Pythagoras (5th century BCE). As noted by Edgar (1986, p. 29), "According to him [Pythagoras] the motion of the planets depended in a mysterious way on music. Not music that could be heard by human ears but sounds which were linked to mathematical principles and which were the distant generators of human music." To connect this idea with the Biblical tradition, Edgar cites Job and the Book of Revelation to corroborate this notion, but with the addition of a personal God in line with theistic worship. From its inception, "when the morning stars sang together and all the heavenly beings shouted for joy" (Job 38: 7 [chap. 38, v. 7]), to its consummation, when "every creature in heaven and on earth and under the earth and in the sea, and all that is in them" will sing to the Lamb on the throne (Rev. 5: 13 [chap. 5, v. 13]), creation is musical: "All nature sings and round me rings the music of the spheres." Music-making thus participates in the music of creation and reflects the order, beauty, and diversity of God's creation. In this direction, Thomas Allen Seel, in A Theology of Music for Worship 
Derived from the Book of Revelation (Seel 1995), has provided a practical example of how a 'theology of music approach' yields valuable insights into the role of music in the Biblical afterlife as found in the New Testament.

Pythagoras and the concept of harmonia had enormous influence throughout the world and especially in the great religions of Judaism, Christianity, and Islam. His discovery of the fundamental sacred nature of musical notes and intervals and their relation to numbers also provided the metaphysical backbone for centuries of musical theory. Philip E. Stoltzfus (2006, pp. 19-20) explains the Pythagorean contribution to both theology and music: "He taught that four musical intervals—the unison, octave, perfect fifth, and perfect fourth-correspond to simple ratios based upon the first four natural numbers, as follows: 1:1, 1:2, 2:3, and 3:4. Using a simple vibrating string, he would have been able to show how each ratio marks the string length necessary to sound the corresponding interval" [In their lowest common denominator, this system is expressed as 6:8::9:12]. The symmetry, simplicity, and aural delight associated with these simple consonantal relations provided the inspiration for Pythagorean speculation upon points, lines, surfaces, planets, bodies, societies, emotive and cognitive states, and concepts of God ... This musical metaphysic naturally went hand in glove with a distinctive religious worldview ... Harmonic theory facilitated in the construction of a concept of the spiritual life, featuring rational movement of the soul or intellect toward apprehension of the ideal proportions of the cosmos. The soul must also become aware of its own 'harmonic' origin, structure, and content in order to realize its analogia with the whole."

Seldom acknowledged, the establishment of Western monotheism is greatly indebted to Pythagoras. Fiorenza and Kaufman (1998, pp. 142-43) have given special credence to the Pythagorean factor in the establishment of the monotheistic idea of God: "The Greek affirmation of the oneness of God goes back to Plato's adoption of the Pythagorean method of seeking explanation in mathematical terms. The ultimate principle of all reality, order, and goodness is to be found in the origin of all numbers, the One. God, the originative source of all being, was not dependent upon any other being, and was thus the sole ultimate, without beginning, without change, without parts, existing from all eternity. This Greek understanding was linked with the Biblical God of Exodus, 'He Who Is (cf. 3: 14), in both Jewish (Philo of Alexandria [c. 20 B.C.E. to 54 C.E.]) and Christian theology."

Stoltzfus (2006, p. 21) enhances the above premise by articulating the musical aspect of Pythagoras in the formation of monotheism: "Pythagorean harmonia [harmony-fitting together] may have been a pivotal concept for facilitating the theological move among some Greek thinkers from polytheism to a critical monotheism." After discussing Plato's work, Timaeus, which has a Pythagorean narrator, Stoltzfus (2006, p. 24) notes how "Clement of Alexandria (c. 150-215) quoted extensively from the Timaeus, finding in the action of the Demiurge the creating logos of Genesis 1 and John $1 \ldots$ Clement identifies Christ as the primordial 'song,' which 'composed the entire creation into melodious order, and tuned into concert the discord of the elements, that the whole universe might be in harmony with it.'" According to several early Christian theologians, in fact, as noted in Stoltzfus (2006, p. 25), "Creation is a musical event, involving the activity of logos to establish cosmic, physiological, and spiritual harmonia out of discord through the power of the Holy Spirit."

Sacred music and classical music in the West thus rest on the strong foundations laid by the Greeks, including the establishment of the diatonic scale and the eight modes of the Christian church. According to musicologist Alec Robertson (1950, p. 12), "Greek music provided the basis of the diatonic scale system out of which the theorists, though not before the tenth century, deduced the eight ecclesiastical modes."

The history of music in the West is subsequently built upon further developments grounded in religious experience laid by two Catholic monks, Guido of Arezzo and Gioseffo Zarlino. Guido of Arezzo (995-1050 C.E.), a Benedictine monk in Italy, wrote a theoretical treatise called the Micrologus (1025-1026 C.E.) and created the Solfeggio or solmization scheme (Do Re Mi Fa Sol La Ti, in its final form) utilizing a religious hymn based on the New Testament. Philosopher Julius Portnoy (1954, p. 65) has described the monumental 
contribution of Guido regarding music: Guido of Arezzo "invented notation and the beginnings of the scale as we know it today ... Guido devised a system which led to the Solfeggio in which we use syllables to read notation. He took the hymn to St. John the Baptist and incorporated the first syllable of each line to indicate a different step of the scale." The hymn is given as follows:

Ut queant laxīs

Resonāre fibrīs

Mīra gestōrum

Famulī tuōrum,

Solve pollūtī

Labī̄ reātum,

Sāncte Iōhannēs.

Translation: So that your servants may, with loosened voices, resound the wonders of your deeds, clean the guilt from our stained lips, O Saint John.

Julius Portnoy (1954, p. 65) further explains the structure of the Sol-Fa system and how it evolved: "A whole tone separated Ut to Re, Re to Mi, Fa to Sol, Sol to La, and from Mi to Fa was a half note. The Ut was later changed to Do and the two initials of the last line in the poem were brought in after Guido as Si to round out the full scale. Guido originally included an extra tone preceding Ut, using the Greek character Gamma, which added to $\mathrm{Ut}$, conceived the term gamut. In subsequent years, the word gamut came to denote the full scale structurally." In the nineteenth century, "Si" was changed to " $\mathrm{Ti}$ " so that every syllable might begin with a different letter.

The great Italian musical theorist, Gioseffo Zarlino (1517-1590 C.E.), a Franciscan monk, was the first to delineate the two types of chords, major and minor, based on their formation from a triad of notes. As understood, the Trinity could be ideally expressed in the form of the musical triad. In his monumental work of 1558, Le Istitutioni Harmoniche, music is described by Zarlino as fundamentally connected with the divine life since it permeates all of creation, as interpreted by Joyce Irwin (1993, p. 51): "Zarlino argues that music is necessary for eternal life. In addition to its comforting properties, it leads to contemplation of celestial matters. Not only is heaven itself populated by nine choirs of angelic spirits, but heaven and earth are united through harmony." And since the Biblical record includes descriptions of music in the highest spheres of heaven, it behooves human beings to cultivate it for fulfillment in the hereafter: "Because the traditional conception of the activity of saints and angels is that they sing praise to God unceasingly, music is regarded either literally or metaphorically as indispensable in the preparation of the soul for heaven" (Irwin 1993, p. 43).

One of the most explicit descriptions of music as Divine Gift is found in the theology of the Protestant reformer Martin Luther (1483-1546 C.E.). This phenomenon is timely for our own exploration into Hindu music, as the lifetime of Luther in Germany (early 16th century) coincides with the apex of the Bhakti movement in northern India and its full attribution of music to divine sources and the acceptance of music as a potent factor in divine-human interaction. Luther's position on the divine origin of music is explained by Robin A. Leaver (2017, p. 70): "For Luther the question of the origin of music cannot be answered simply in terms of history, chronology, or human progenitors; indeed, the question cannot be understood, let alone answered, without recourse to theology, since music per se was not invented by humans but rather created by God. Repeatedly in his writings Luther states that music is the donum Dei, the gift from God, and therefore is only secondarily a human art or science ... For Luther, therefore, music is a God-given benefit to humankind: it may be developed and refined in new ways, but the raw material of music - physical vibrations in the air, the proportions and relationships of different pitches and so forth-is absolutely and fundamentally the gift of God in creation." Luther thus went beyond both Jubal and Pythagoras in asserting that music is not a human invention, but a gift of God that they both discovered and developed. "When thinking about the origins of music Luther had a more fundamental approach compared to that of his medieval 
predecessors. For him it was beside the point to discuss the primacy of either Jubal or Pythagoras since neither invented music." For Luther, then, even though music was part of creation, it was a Divine Gift at the time of creation to be utilized in worship.

Even prior to Zarlino, the notes of music for Lutherans held sacred status by their connection to the Trinity. According to Leaver (2017, pp. 98-99), "In music (the Trinity is expressed) in the three notes Re, Mi, Fa ... Luther chose the three notes Re, Mi, Fa [D E F], which embrace the two fundamental intervals of the musical scale-a whole tone between $\mathrm{Re}$ and $\mathrm{Mi}$, and a semitone between $\mathrm{Mi}$ and $\mathrm{Fa}$ - the two intervals on which music depends. Thus $\mathrm{Re}, \mathrm{Mi}, \mathrm{Fa}$ is as fundamental to music as the doctrine of the Trinity is fundamental to theology .... With the beginnings of the shift from modal to major/minor tonality in the later sixteenth century [by Zarlino], Luther's melodic Trinitarian model was re-interpreted harmonically. Instead of a succession of adjacent notes (D, E, F = Luther's Re, Mi, Fa) the Trinitarian harmonic triad (Latin trias) became the model (C, E, G)." Thus, there was mutual agreement among Christian groups in the divinity of the Triad. One does not need to venture far to realize that many of the most renowned and prolific composers of both sacred and classical music (i.e., Schutz, Buxtehude, Pachelbel, Telemann, Bach, Handel, Mendelssohn, Brahms) were Lutheran or inspired by Luther's theological position on the divine origin of music.

Another poignant theme relating to theology of music in the West is the presence of musical angels in heaven and at the time of creation. Kathi Meyer-Baer (1970, p. 5) explains how angels are inextricably bound to music through the ancient Greek notion of harmony of the spheres: "The image of angels singing, playing, and dancing to praise the Lord may be traced back to early concepts of the music of the spheres, as well as to the idea of harmony in the universe expressed through music ... The transmutation of the early pagan figures of the movers of the spheres into Christian angels, as well as of their association with music." Meyer-Baer (1970, pp. 40-41) then describes how the development of Western classical music and Christian theology paralleled the spiritual notions of heavenly angels and divine beings: "By the eleventh century, the various traditions of cosmic and angelic orders had merged, and the vision had assumed an aspect familiar today: the blessed sing and dance in the highest heaven, be it Elysium or Empyrean. There are nine spheres or heavens and nine choirs of angels. The spheres are moved by angels or the Muses. Their song results in the harmony of the universe, and this harmony can be transmitted, through music, to the human soul."

The terrain of theology of music is greatly enhanced as one broadens the scope of inquiry to include the Eastern traditions. In several Eastern religions, including especially Hinduism, we find music as Divine Gift as well as musical angels who populate heaven and the spiritual realm. Joscelyn Godwin (1987, p. 73) discusses musical angels in both Western and Eastern contexts, pointing to the principal topic of inquiry in this article, the theological underpinnings of Indian classical music: "All religious traditions that acknowledge the existence of angels concur to giving them musical attributes. Since it is not clear in visual representations when someone is singing, they are usually given musical instruments to make their function plain. One can see such angels in the courts of heaven as pictured in Iranian manuscripts. They appear in Hindu temple sculptures as the seductive Gandharvas, of whom the Mahābhārata has much to tell."

\section{Theology of Music and Hindu Religion}

We now turn to our principal focus, theology of music in the Hindu tradition. While one might assume that music had a separate history in ancient India, it is important to underscore the abiding connection between sacrifice, religious observance, and the emergence of music or Sangita. Sangita is associated with the Hindu gods and goddesses, who sing and play instruments and serve as originators of the art of music as a Divine Gift. Music is also associated with metaphysical principles like OM and Nāda-Brahman, the Sound Absolute that is articulated in theistic, Tantric, and musicological literatures. As 
a preface to sacrificial rites and Mantras, $\mathrm{OM}$ is also believed to be the source of all the musical notes and their permutations.

\section{Divine Gift and Musical Angels}

The Trimurti or the three Great Gods of Hinduism, Brahmā, Vishnu, and Śiva, hold prominent positions regarding music and its transmission to human beings. Lord Brahmā, the Creator, fashioned Indian music out of the ingredients of the Sāma Veda, and plays the hand cymbals. Vishnu, the Preserver who sounds the conch shell, plays the flute in his manifestation of Krishna. Śiva the Destroyer, as the dancing Națarāja, plays the Damaru drum during the dance of cosmic dissolution and is the originator of rhythm. The Goddess Sarasvatī, wife of Lord Brahmā, holds and plays the Vina instrument, and is the divine patroness of music. As an essential aspect of life in heaven among the Gods, music was presented to human society as Divine Gift, including all aspects of theory and practice. Ancient music was also known as Gandharva, since it was played by musical angels known as Gandharvas, a class of male singers and demigods led by Nārada Rishi, the son of Brahmā who resides in heaven but is capable of journeying throughout the universe. The Gandharvas are accompanied by their wives, the dancing Apsarās, and the Kinnaras on musical instruments. The arts, including vocal music, dance, and instrumental music, are thus considered divine, being performed by divine beings. Besides authoring seven hymns in the Rig Veda (and the Sāma Veda), Nārada Rishi is believed to be the inventor of the Vina and the sage who instructed human beings in Sangita, having learned it from the Goddess Sarasvatī who had received it from Brahmā himself.

The narratives of the Gods and their heroic deeds came to form the substance of Indian sacred lore, many of which were ritually reenacted in sacred dramas. The oldest surviving texts describing Gandharva Sangīta are the Nātya-Śāstra by Bharata Muni and the Dattilam by Dattila (both ca. 400-200 B.C.E.). They provide descriptions of the music performed in sacred dramas, festivals, courtly ceremonies, and temple rituals. The sacred dramas known as Nātyas began with special ceremonies of worship called Pūjā. Gandharva Sangīta was associated with these Pūjās and dramatic performances. Considered a replica of music performed and enjoyed in heaven, Gandharva Sangìta and the service of Pūjā are believed to have been received on earth as part of heavenly dramatic performance and worship of the Trimūrti.

The Nātya-Śāstra describes the divine origin of music and its presentation to humans as a Divine Gift. At the beginning of the text the author Bharata Muni explained that in a previous age Brahmā composed a "Fifth Veda" known as the Nātya-Veda by taking recitative from the Rig Veda, music and song from the Sāma Veda, ritualistic and histrionic representations from the Yajur Veda, and aesthetic sentiments from the Atharva Veda. This was to be performed for moral upliftment and instruction in the various disciplines, arts, and crafts, for persons who were incapable of hearing and understanding the Vedas. Brahmā initially wanted Indra to pass the project on to qualified gods, but he replied that none of the gods would be willing or able to do it and suggested giving the art of drama to the sages. Brahmā then requested Bharata Muni and his 100 sons to take up the duty of play production, which involved vocal and instrumental music. The sage Svāti and Nārada Rishi both engaged to help Bharata Muni. Under Brahmā's order, Svāti and his disciples were employed to play on musical instruments (drums) and celestial musicians (Gandharva) such as Nārada Rishi and others sang songs. After fully understanding the dramatic art (nātya) which arose out of the Vedas and their various parts, the sage Bharata with his sons as well as Svāti and Nārada Rishi approached Brahmā with folded palms and, stating that they had mastered the dramatic art, prayed for his command. Brahmā then ordered that a play be performed in honor of Indra's conquest of the demons. Being well-pleased with the performance, Brahmā then ordered the construction of a theatrical stage in heaven and instituted the regular offering of Pūjā (worship) to all the gods. According to Brahmā, drama was designed to be a unique and comprehensive method of religious teaching and 
moral instruction. Vocal and instrumental music were central to all performances and worship (paraphrased from Rangacharya 2003, pp. 1-5).

The narrative continues with a description of how music and drama descended to earth. In due time Bharata's 100 sons, under the effects of intoxication, offended the sages by caricature and mockery. Angry, the sages cursed the sons to become Sūdras. In response, the gods headed by Indra were worried that drama would hence disappear as an art form. The sons, out of sadness and desperation, threatened to kill themselves but Bharata Muni comforted them and told them to perform acts of purification. Meanwhile King Nahusā, who had gained heavenly status, observed the dramatic performances and then desired to have these spectacles performed in his own palace on earth. Though the gods refused to lift the curse of the sages, Bharata arranged to send his sons to earth to perform the music and drama, and the curse was lifted. Bharata's descendants Kohala, Vatsya, Sandīlya, and Dattila were ordered to stay on earth as mortals to carry on the tradition by writing treatises and teaching (paraphrased from Rangacharya 2003, pp. 341-45).

Established on earth, Sangita came to be recognized for its spiritual quality and was believed to be more efficacious than all other forms of religious observance. The NātyaŚāstra (chap. 36. v. 27) states: "Music, both instrumental and vocal, dance and songs are equal to the recitation of Vedic Mantras. I have heard from the great God Śankara [Śiva] himself say that music is a thousand times superior to bathing in holy waters and to japa [chanting divine names]" (Rangacharya 2003, p. 342). Sangita also had the power to remove evil forces and inauspiciousness. Music is in fact double-edged: a vehicle awarding liberation (Mokșha) that is also designed to please the senses. Combining the aesthetics of Rasa theory with the structures of Rāga (melody types) and Tāla (rhythms), Sangīta has influenced all branches of Hindu religion.

\section{Primal Sound and Sacrifice}

One of the pioneers of comparative musicology, Marius Schneider (1903-1982) described primal sound, especially praise song, as the first form of sacrifice in an article first published in 1964 (Schneider 1989, pp. 37-38): "Song, according to the ancient concept, did not accompany the sacrifice but in fact formed the core of the sacrificial process ... What resounds at the beginning of all things is a praise song. This song represents the first sacrifice ... Sound is the basic matter of the primordial world. Praise is the dynamics of this sound." Schneider's comparative approach has noted that the Vedic tradition of ancient India is the oldest tradition relating sacred sound, in the form of the syllable OM, to sacrifice: "Sacrifice is the crimson thread that runs through the whole of human life. If this sacrifice is a sound sacrifice, a praise song, then man taps into the primordial acoustic energy of creation, which in the final analysis is the holy syllable AUM [OM] that 'fastens' everything together: the past, the present, and the future." Earlier, Rudolf Otto (1958, pp. 192-93), after his deep study of Indian religion and Hindu experience, had verified the numinous quality of the ancient syllable OM: "Another original sound in which numinous feeling is articulated is certainly the holy syllable ' $\mathrm{OM}^{\prime}$ '... sounding up from within as the quasi-reflex expression of profound emotion in circumstances of a numinous-magical nature,... almost physical in its constraining force. And this constraint and compulsion to expression are still recoverable to our feeling when we recapture this mood of submergence and absorption in the 'wholly other.'"

In ancient India sacrificial rites included the chanting of OM as well as Vedic hymns to the various gods. OM was a special utterance that was discovered by sages in deep meditation that served as a practical tool for invocation and application as a preface to the verses or Mantras that accompanied oblations into the sacrificial fire. Without Mantra, there was no sacrifice, and without OM there was no Mantra. Verses from the Rig Veda in the form of Mantra were chanted by special priests. These Mantras were expanded in Sāma-Gāna, the singing of hymns from the Sāma Veda during Soma sacrifices involving the offering of Soma juice. Recent research on the origins and history of the syllable OM has revealed that OM was associated with the Sāma Veda and tonal chant and music from 
the beginning of its use.in ancient India. According to Finnian Gerety $(2015$, p. 401), “The bottom line is that the first thousand years of OM constitute a Sāmavedic movement within the broader religious culture of Vedism. Amidst concurrent contributions by experts from the other Vedas, it was the singer-theologians of first the Jaiminīya, and then the Kauthuma, branches of Sāma Veda who did the most to foster OM's emergence. In my view, this is the single most important finding of the present study: that the history of the sacred syllable resounds with music and song."

The Sāma Veda hymns were believed to possess supernatural powers capable of petitioning and supporting the deities that controlled the forces of the universe. G.U. Thite (1997) has enumerated the dynamic role of music in these rites: 1. Gods and music are connected in the Veda. 2. Music has an attractive power. It attracts the gods. Music also goes to the gods. One may please the gods with music and ask them to come. Gods are fond of music. They enjoy it. 3. One barters with gods by means of music and gets the desired results granted by them. 4 . Music helps gods in many ways. Particularly it is often said that it strengthens them. Gods use music and get their desired results. They come under the influence of music and are sometimes inferior to music. 5. Sometimes, however, they themselves help the music in various ways and are superior to it. 6 . Thus music has got a magico-religious role in connection with the gods. The singing of Sāman hymns was essential to the sacrifice such that without it no sacrifice could reach the gods.

The continued high status of OM in all Hindu traditions cannot be over-emphasized. $\mathrm{OM}$ in its triplicate form of $\mathrm{A}+\mathrm{U}+\mathrm{M}$ is identified in the Puranna literature with the great gods of Hinduism, especially the Trimūrti of Brahmā (A), Vishnu (U), and Śiva (M). In the Vāyu Purāna, OM is identified with the Trimūrti. The Mantras 'Hari OM' and 'OM Namo Nārāyañăya' are directed to Lord Vishnu as showcased in the Vishnu Purāna, and the popular Mantra, 'OM Namah Śivāya' is chanted to Lord Śiva, the principal deity of the Śiva Purāna. The Bhagavad Gītā proclaims that the syllable OM is none other than Lord Krishna. In Hindu lore, the universe is periodically destroyed and then created again by Lord Brahmā. At each creation, the seed-syllable OM enters the heart of Brahmā and allows him to create the elements of nature as well as the innumerable bodies that must be fashioned on earth. From the sound of OM, Brahmā articulates the Sanskrit words that correspond to the elements and living beings, and thus everything is created. After creation, Vishnu preserves the cosmos for thousands of years until everything is again destroyed by Siva. In each phase, the syllable OM endures. Moreover, the Yoga tradition outlines a course of spiritual attainment utilizing OM to reach the state of Moksha or liberation. Accordingly, the practice of chanting OM is prescribed by Patañjali in the Yoga Sütra as a useful means to focus one's attention on İśvara, the Lord of the Universe.

\section{Metaphysical Principles}

Musical sound in ancient India was also grounded in key metaphysical concepts which are nonetheless linked to theology. Demonstrating a "sonic theology" (see Beck 1993), the Hindu tradition has embraced divine sound as a form of the Absolute known as Brahman through the concept of Nāda-Brahman ("Sacred sound as God"), composed of Nāda-Śakti (sound energy, represented by the half-moon in the symbol of OM) and Brahman (divine Absolute, represented by the Bindu or seed in OM). Beside linguistic sounds and utterances as normally connoted through the term Śabda-Brahman, NādaBrahman encompasses musical sounds and refers to the cosmic sound that may be either unmanifest (anāhata, "unstruck") or manifest (āhata, "struck"). As unmanifest, Nāda is only perceived in the heart during deep meditation (i.e., Nāda-Yoga). As manifest, it is expressed through music and song. The notion of Nāda-Brahman was developed more fully in the Āgamas, Pāñcarātras, and Tantras as well as in Yoga and musicological texts. While musical treatises discuss Nāda-Brahman as the foundation of musical sound, Yoga texts speak of musical sounds heard during deep meditation, as in Nāda-Yoga. Whether in Vaiṣnnavism (Vishnu or Krishna worship), Śaivism (Śiva worship), or Śaktism (Goddess worship), the concept of Nāda-Brahman ('sacred sound') is employed to affirm that God 
or the Supreme Being contains the elemental of primal sound and can be approached in deity form through sound and music. True meditation on a deity involves both sound and image, and the name of a deity was understood to contain all the spiritual potencies of the deity.

Nāda-Brahman appeared in the context of music in the eighth century C.E., where it appears in a text known as the Bṛhaddeśî by Śrī Matanga Muni. Śrī Matanga Muni's Bṛhaddeśi provides us with an early formal connection between Nāda-Brahman, music, and the Hindu deities of the Trimurtī: "There is no gìt $\bar{a}$ (song, music) without nāda [NādaBrahman], there are no svaras (musical notes) without $n \bar{a} d a$, there is no $n r t t a$ (dance) without $n \bar{a} d a$, hence the world is of the essence of $n \bar{a} d a$. Brahma is known to be the form of $n \bar{a} d a$ (nāda-rūpa), Janārdana Vishnu) is of the form of nāda, Parā Śakti is of the form of nāda (and) Maheśvara [Śiva] is of the form of $n \bar{a} d a .{ }^{\prime 1}$

The importance of Śrī Matanga Muni for stimulating more attention to Nāda-Brahman and other features of Yoga and Tantra is such that nearly all subsequent musicological authors discuss Nāda-Brahman in relation to musical sound production and Hindu worship, both in the cosmos and in the human body. The most famous example is Sangita Ratnākara of Śārngadeva (ca. 1200-1250 C.E.), which opens with the following salutation: "We worship Nāda-Brahman, that incomparable bliss which is immanent in all the creatures as intelligence and is manifest in the phenomenon of this universe. Indeed, through the worship of $n \bar{a} d a$ are worshipped gods Brahmā, Vishnu, and Śiva, since essentially they are one with it." ${ }^{2}$ The author of this text proclaims his allegiance to Siva at the outset: "For delight do I worship Lord Śiva in (the form of) nāda, pre-eminently adored by the entire world." ${ }^{3}$

The Sangita Ratnākara then proceeds with the statement about Nāda-Brahman being the source of all kinds of musical sound as well as dance and language: "Nāda is the very essence of vocal music. Instrumental music is enjoyable, as it manifests nāda. Nrttta (dance) follows both (i.e., vocal and instrumental music); therefore, all the three together depend on $n \bar{a} d a$. Näda manifests the letters (of alphabet), letters constitute the word, and words make a sentence; so, the entire business of life is carried on, through language; and therefore, the whole phenomenon (i.e., the world) is based on nāda." Nāda-Brahman may be either unmanifest (anāhata, "unstruck," existing in the divine realm) or manifest (ähata, "struck," existing in the human realm, i.e., music). As stated in the text, "Nāda is said to be twofold, viz., produced and unproduced. Since it manifests itself in the human body, the (process of) embodiment is being described." ${ }^{5}$

Other musical treatises and lineages developed these axioms and laid the groundwork for the theories of classical and devotional music of the present-day. The Sangitopanișatsāroddharah, a manual on music written in $1350 \mathrm{CE}$ by a Jain scholar in Gujarat, discusses theories of OM and Nāda-Brahman. It begins with a description of musical sound (Miner 1998, p. 7): "The primary sound (Nāda) is produced from the body, which consists of Siva and Śakti, and is formed of the five elements ... (Miner 1998, p. 7), "Sound [Nāda] arises from the body, and song [Gītā] comes into being from sound." (Miner 1998, p. 9), "The three gods Brahmā, Vishnu and Maheśvara, consist of Nāda. Parabrahmā, Paraśakti and the sound OM are produced from Nāda." Another interesting feature is the reference to the pastimes of Lord Krishna in the origins of Rāgas (Miner 1998, p. 91): "There are as many Rāgas as there are species of creatures. The Rāgas number sixteen thousand. They are said to have been made by the Gopīs [Krishna's female companions]."

\section{OM and Music: From One Sound, Many Notes}

Embedded at the core of the Hindu tradition, it is not surprising then that the syllable $\mathrm{OM}$ became the foundation of Indian music, both theoretically and practically. Music treatises in Sanskrit hold that all music originates in OM and dissolves in OM via the principle of Nāda-Brahman. Since music has always been associated with Hindu worship and devotion, it is not surprising that the syllable OM has a lasting connection with Indian music. Just as the chanting of OM inaugurates Vedic sacrifice and worship, classical and 
devotional singers begin with the base note or tonic (Sa) in the form of OM. Music-making is prominent throughout India, but whether amateur or professional, musicians consistently begin recitals with $\mathrm{OM}$ as a matter of respect for their Guru and tradition. The chanting of $\mathrm{OM}$ is rendered like a steady drone-like sound on the tonic note. After the initial OM, the sound is expanded by singers to include the entire gamut of notes (Svaras) relevant to a specific Rāga or melodic formula employed in the song or composition. Other syllables may be used to create an elaborate introductory section to a composition that is then set to a rhythm and accompanied on a drum. It is understood that all the notes in Indian music-including those produced by instruments- flow out of the initial OM. The musician ideally serves as the vessel for the manifestation of Nāda-Brahman, in that the voice acts as an access point for singers, and the hands and fingers for string, flute, and drum players. At the conclusion of the music, the voice or instrument fades away on the tonic drone sound in recollection of the initial OM. India recognizes the immense power of vowel sounds to convey deep spiritual meaning such that the slow and elongated reverberation of vowels in the throat is identified with the manifestation of Nāda-Śakti, the potency of Nāda-Brahman. The unmanifest Nāda may exist beyond our perception, but when we exercise our voice in speaking, chanting, or singing, we release the potency of Nāda in the world of the senses.

The association of Nāda with OM, and with the succession of musical elements like Jāti (the parent of the Rāga), Śruti, and Grāma, is brought very clearly in the Sangīta Ratnākara ( Shringy and Sharma 1978, pp. 1-3): "For delight do I worship Lord Śiva embodied in (the form of) Nāda, pre-eminently adored by the entire world, the source of order inherent in the division of the domains, the organization of castes and the distinction of species; who being manifest in the heart-lotus of Yogins as Omkāra [OM $\}$ in the contemplation of the mind united to the movement of Prāna [life air] originating from the root of the navel, shines in its own lustre (1). Interpretation with reference to music: I take pleasure in paying homage to Gitam, the embodiment of Nāda, the cause of comfort in the restless world, the source of the system comprising the division of Grāma, the composition of Varnas, the Alankāra and the Jātis [the parent of the Rāgas], the self-manifest locus of Śrutis that delights the masters of music in the lower register, aided by the mind attuned to the movement of Prāna originating from the root of the navel." Nāda is stated to be threefold according to its manifestation in the human body (Shringy and Sharma 1978, p. 114): "The Threefold Nāda in Music: ... in actual practice it is threefold, called Mandra in the heart, Madhya in the throat, and Tāra in the head and is successively double in pitch." Beyond this triplicate manifestation, Nāda is subdivided into 22 Śrutis (Shringy and Sharma 1978, p. 115), "Nāda is differentiated into twenty-two grades which, because of their audibility, are known as Śrutis." From the Śrutis arise the seven musical notes (Shringy and Sharma 1978, p. 130): "From out of the Śrutis arise the Svaras; these are seven, viz., Sadja, Rṣabha, Gandhāra, Madhyamā, Pañcama, Dhaivata, and Nișāda. Their other accepted nomenclature is Sa-ReGa-Ma-Pa-Dha-Ni." This pattern of the Svaras and Rāgas emerging out of Nāda-Brahman is replicated in the lyrics of the later compositional forms of Dhrupad and Khayal, as we shall see.

The systematic emergence of musical notes (Svaras) 'out of $\mathrm{OM}^{\prime}$ can be more easily understood in this way. In ritual, the chanting of OM was normally done in a monotone, followed by verses from the Rig Veda chanted in roughly three distinct musical tones or accents. These were expanded to five to seven notes in the singing of the hymns (Sāmans) from the Sāma Veda (ca. 1000 B.C.E.). As part of the evolution toward the establishment of the present-day Indian scale, the original descending Sāma Veda scale was gradually recast into a new ascending and descending seven-note structure in Gandharva Sangīta, corresponding to the standard scale of seven notes in the form of the Sargam-Sa Re Ga Ma Pa Dha Ni-in the Nātya-Śăstra of Bharata Muni and the Dattilam. In Dattilam, the term used for the seven notes (Svara-Saptaka) is Svara-Mandala-circle of notes. This usage resonates well with the term Mandala in the Nătya-Śăstra as a circle of the Gods in the preliminary Pūjā rituals. 
In the Nāradiya-Śiksa (first century B.C.E.), Nārada (an historical person, not the Vedic sage) explained how these seven ascending and descending notes were directly determined from the original three Vedic accents: Udatta into Ni and Ga, Anudatta into Re and Dha, and Svarita into Sa, Ma and Pa. The seven notes are also named here, metaphorically, after the sounds of different birds and animals:

Sa-peacock

Re-bull

Ga, ram

Ma-crane

Pa-cuckoo

Dha-horse

Ni-elephant.

The notes, Re Ga Ma Dha Ni, are also modified with raised or lowered half-notes (like the Western sharp and flat notes) to create multiple variations of scale formulas, while the tonic $\mathrm{C}(\mathrm{Sa})$ and the dominant $\mathrm{G}(\mathrm{Pa})$ generally remain fixed. These notes are also shortened for convenience as S R G M P D N. Still employed today, these seven notes roughly correspond to the Western Solfeggio discussed above or simply the diatonic scale of C D E F G A B. A principal difference is that there is no harmony or chord structure in the Indian system of music.

The metaphysical notions, divine origin narratives, and sacred musical technicalities discussed above have not faded away into posterity but have retained a viable presence in the lyrics of numerous Indian classical songs. The musical themes and terminology of the ancient and medieval texts on music, including references to sacred sound as $\mathrm{OM}$ and Nāda-Brahman, origins of types of vocal music, instrumental music, musical instruments, musical notes (Svara), melodic patterns (Rāga), and cyclical rhythmic patterns (Tāla), reappear especially in the lyrics of the classical music compositions of Dhrupad and Khayal. This is significant because a common misconception is that classical music developed in the secular courts and in dramas separately from the theistic traditions and from the theological texts and teachings of Hinduism. Part of this divide is due to languagetheological texts are in Sanskrit and classical music is predominantly sung in the vernacular. We will now demonstrate several references to the sacred origins of music in the vernacular lyrics of classical songs. The continuity of the theology of music with current classical performance, acknowledged by many musicians, scholars, and musicologists, makes the religious dimension more relevant and worthy of investigation.

\section{Dhrupad and Khayal Musical Compositions}

Northern Hindustani music in its present form originated from the late medieval tradition of Dhrupad, formalized music performed in the ruling courts of Rajasthan, Maharashtra, Gujarat, Bengal, and Uttar Pradesh, from ca. 1400-1600 C.E. The structure of Dhrupad was an ideal vehicle for vernacular lyrics containing descriptions of deity and theological reflections on the origin of music. After an unaccompanied vocal introduction, Dhrupad unfolds into a four-section rendition of a poem using the pure form of a Rāga and set to the rhythm of mainly Cautal (12 beats) and Dhamar (14 beats). In due time Khayal became fashionable in the courts yet retained its largely religious and spiritual content.

The following musical examples in the Dhrupad and Khayal genres express the basic philosophy of sacred sound and music in the Hindu tradition by portraying the origin of notes and Rāgas from OM and Nāda-Brahman, and from Anāhata to Āhata. The Dhrupad compositions are set to Rāgas and the rhythm of Cautal of 12 beats or Jhaptal of 10 beats. The Khayal compositions are set to Rāgas in the rhythm known as Teental of 16 beats. All examples are from the received canon of Hindustani compositions. The published compositions are referenced from two standard anthologies (Bhatkhande [1963] 1974, and Patvardhan [1960] 1970), while the unpublished songs were received from a Guru in an authentic musical lineage. 
The first example is a standard Dhrupad composition in Rāga Malkauns (Bhatkhande [1963] 1974, vol. 3., pp. 742-43), which venerates Nāda-Brahman as the source of all true wisdom that is only received from a Guru.

Nāda ko vistāra kara ke dikhāve tohī mai jānūn vāko baḑo jūāna

Je je guni te te saba, jānata yaha kațhina bāta, Guru se pūchale yah̄̄ jũāna

The greatest knowledge is that of the mystical Nāda and its numerous manifestations. Many learned scholars affirm that this precious wisdom is only available from a Guru.

The next selection is in Rāga Multani (Patvardhan [1960] 1970, vol. 2, pp. 128-29). The straightforward pronouncement of the link between OM and Nāda-Brahman is followed by the manifestation of the seven notes and the three scales. The second line mentions the characteristic patterns of Tānas and Murcchanās, as well as the 22 microtones or Śrutis.

Prathama Nāda Orikāra, tina Grāma Sapta Sura gāvata gunijana kara vicāra Unacāsa koti Tāna, ikaisa Murcchanā, baisa Sura gāvata ākāra

In the beginning was the sound of OM, as Nāda-Brahman. From this emerged the three musical Grāmas or scales, and the seven Svaras or notes (Sapta Sura) for singing as explained by the learned. From these are created the various patterns, like 49 Tānas, 21 Murcchanās, and 22 Śrutis or division of notes.

The famous Dagar Brothers are the pre-eminent performers of Dhrupad in the modern world. Although members of the religion of Islam, they embrace the veneration of OM and Nāda-Brahman as the wellspring of music in this composition in Rāga Bhairav

$\bar{A}$ da Nāda Orikēara hota kharaja sākāra ja ke śruta dhare cāra

Tāson rikhaba gandhāra madhyama sura ko singāra

Pañcama so ādhāra dhaivata śruta tīna dhāra nikhāda kī doū hai

The primal sound or Nāda-Brahman, which constitutes OM, is the basis of the seven musical notes (Sura/Svara) Sa-Re-Ga-Ma-Pa-Dha-Ni and their multiple Śrutis.

The next Dhrupad in Rāga Shankara salutes Nāda as the source of Rāgas and Tālas, etc. but also as a means of alleviating misery and establishing pure love (Prema Bhakti) through song, instruments, dance, and acting. It was composed by Pt. S. N. Ratanjankar, a pre-eminent vocalist, scholar, and composer of the twentieth century. As a disciple in the Agra Gharana, he composed Dhrupad and Khayal compositions of great merit (see Mutatkar 2001).

Namo namo namo Nāda, aprampāra he

Sura nara muni Gandharva gunī

Tava jasa guna gāye, pāye ata ānanda he

Rāga Tāla sura laya ten, nāma liye hi saba

Dukkha danda mitata jāta

Prema Bhakti rasa ranga son

Gìta vādya nritya națata

Dhana dhana dhana he

Triple veneration to the boundless Nāda, whose glory is praised in song by sages and intelligent men schooled in ancient music or Gandharva, achieving endless bliss. Receiving Nāda in the form of Rāga and Tāla, notes and rhythms, all miseries and pains are mitigated. And with the aid of songs, instruments, dance, and theatrics, the flavor of pure love is attained. Glories upon glories to Nāda!

We cite another Dhrupad composition in Rāga Yaman, by Pt. S. N. Ratanjankar

$\bar{A}$ da Nāda brahma Nāda, anāhata Orikkāra pranava, jāko joḡ̄ dhyāna karata pāvata sat-cid $\bar{a}$ nanda

Hari mukha te āhata, nikasyo madhura murali nāda, yate akhila carācara, pāyo parama sukha ānanda

Udātta aru Anudātta Svarita liye tīna bheda jāmen pațhata Veda mantra mārga rīta āhata Nāda 
Tāhi son Sapta Sura deśí rīta mon pramāna prakața nāma rūpa son, kharaja rikhaba gāndhāra madhyama pañcama dhaivata, nikhāda śuci vikrita bheda

Nāda-Brahman is the primal sound represented in OM, which is unmanifest. Great Yogis contemplate this with bliss. The manifest Nāda emanates from Krishna's flute, giving great joy to all sentient beings.

The Vedas describe three accented notes, Udātta, Anudātta, and Svarita used in Mantras. From these three accented notes emanate the seven notes (Sapta Sura), as named.

The next song is in Rāga Shivmat Bhairav. It is a Dhrupad-style composition in Jhaptal (10 beats), also composed by Pt. S. N. Ratanjankar.

Prathama Orikāra dhvani, tāte anāhata, gupta Nāda āhata dujo prakața hota,

Sapta Sura tīna Grāma, ekaisa Murchanā, Rāga Rāgiñ̄ rūpa āhata te nikasata

The primal sound is OM which is composed of Nāda-Brahman. From its original state of being unmanifest and hidden, Nāda became manifest in the world in the form of the seven musical notes (Sapta Sura), the three scales (Tīna Grāma), and their many variations (Murcchanā). Out of these the Rāgas and Rāginīs were manifest.

While Dhrupad was prevalent in the northern Hindu and Muslim courts for several centuries, by the nineteenth century Khayal had virtually replaced it as the predominant form of Hindustani vocal music, and by the twentieth had become the showcase of the concert stage and All India Radio. Khayal, sung in the vernacular Braj Bhāṣā dialect, retained an affinity with the religious nature of the Dhrupad songs. Sung by both Hindus and Muslims, Khayal allowed for more freedom in improvisation, more complex Tāla patterns, and diversification into separate 'houses of tradition' known as gharānās. The presence of Persian and Sufi culture also gradually influenced its development. But despite differences in religious belief and theology, Hindu, Muslim or Jain, Khayal continued the affinity with the original spirituality of Dhrupad. Although there was greater emphasis on creative vocal stylings, the lyrical content of Khayal, with some exceptions, continued to refer to philosophical ideas found in ancient texts, the description of deities, the praise of God through emphasis on Nām-Kīrtan (chanting of divine names), or simply the human longing for the Almighty.

The following Khayal composition in Rāga Malkauns, composed by Pt. S. N. Ratanjankar, is a suitable counterpart to the Dhrupad composition in Malkauns cited above.

Nāda bheda aparampāra guni Gandharva hāre kara bicāra śruti sura murcchanā mela Jāti Rāga bistāra mārga ati kațhina jñāna

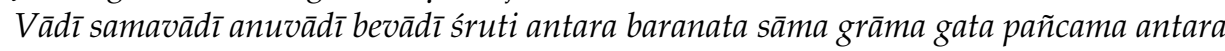
mānata śāstra kāra śruti pramāna

The original sound of Nāda is boundless and infinite. According to those sages learned in the ancient art of music or Gandharva, from Nāda is derived the musical Sruti (microtones), Sura (notes), Murcchanā (scale variations), Jāti (scales), Rāgas, and their expansion.

According to musical texts, this advanced knowledge of music as described also includes concepts like Vādī (primary note), Samavādī (secondary note), Anuvādī (supporting note), and Bevādī (conflicting note).

The following Khayal song is in Rāga Yaman (Bhatkhande [1963] 1974, vol. 2, pp. 31-32), and vividly demonstrates the continuity between Nāda-Brahman, the seven notes, and Yoga physiology.

Āhata anāhata bheda Nāda ke, prathama bheda śrutiyana so hove, anāhata munijana dhyāna dharata jaba

Nābhi kantha aura murdha sthāna son, mandra madhya aura tāra hovata,

Sapta Surana ke nāma bakhāne, Sa Re Ga Ma Pa Dha Ni sa Ni Dha Pa Ma Ga Re Sa

Nāda-Brahman is divided into two realms, āhata or 'struck' sound and Anāhata, or 'unstruck' sound. The struck sound is then divided into 22 Śrutis or microtones. The ancient 
sages meditated on the Anāhata dimensión of Nāda-Brahman, being in touch with Divine Truth.

The seven notes, Sa Re Ga Ma Pa Dha Ni, are distributed over three octaves. The three registers, lower (Mandra), middle (Madhya), and higher (Tāra), correspond to the three levels of the body; the navel, throat, and head.

This composition is available in audio and video format performed by the author, from the CD, Wisdom of the Khayal Song (Beck 2016), https://www.saavn.com/song/ ahata-anahata-bheda-nade-ke---raag-yaman/GDcxRDkGcls Video online: https: / www. youtube.com/watch?v=gLOjOl5AvAM, (accessed on 18 August 2021).

\section{Conclusions}

After discussing some of the Vedic and Hindu concepts and practices relative to sacred sound and music in India, we have demonstrated the continuing reverence for the sacred concepts of OM and Nāda-Brahman and the narratives of music as Divine Gift within the traditions of Indian classical music and especially as contained in the songs of the current Hindustani classical traditions of Dhrupad and Khayal. The compositions we have cited carry forth into present practice the medieval scholastic references in the musical texts and provide devices for learning and memorization of the basic principles. And while singers of different religious persuasions, Hindu, Islamic, and Jain, have dedicated their lives to the music of Dhrupad and Khayal, they each acknowledge the legacy of divine origins of the classical music and continue to compose and perform songs that exhibit the themes outlined in this article.

We have also indicated compelling features in the Greek and Biblical traditions of sacred music, suggesting a comparative dimension for a broader theology of music. There are many similarities and differences between Western and Eastern traditions of sacred music, enough material in fact to generate volumes of research. But while this article is not a 'comparative study,' we have noted similarities in music as a Divine Gift, the presence of musical angels, and the sacrality of musical notes on both sides of the spectrum. One important difference is that there is no corresponding single 'sacred syllable' like OM in the West from which music derives, since Western music relies more on the rational and unified development implicit in the Pythagorean system of harmony.

Regarding the Indian situation, we conclude that classical compositions in the current repertoire of Hindustani classical music reflect an allegiance to the ancient and medieval principles of sacred sound and the divine origins of music as found in Hindu literatures and traditions. Moreover, it is hoped that more research in the field of theology of music with a comparative lens will enable further insight into, and conversation with, the Indian accounts of the origin of music and the unfoldment of notes and melodic patterns.

Funding: This research received no external funding.

Institutional Review Board Statement: Not applicable.

Informed Consent Statement: Not applicable.

Data Availability Statement: Not applicable.

Conflicts of Interest: The author declares no conflict of interest.

\section{Notes}

1 Bṛhaddeśī of Śrī Matainga Muni. 18, 19. Sharma (1992), trans, p. 7. na nādena vinā gìtaì na nādena vinā svarah/na nādena vinā nụttaì tasmād nādātma kaỉ jagat. //18// nāda-rūpah smṛto brahmā nāda-rūpo janārdana/nāda-rūpā parā-śaktir nāda-rūpo maheś varah //19//.

2 Sañgìta Ratnākara of Sārngadeva. Vol. 1.3.1-2. Shringy, trans., pp. 108-9. caitanyaì sarva-bhūtānāim vivrttaì jagad-ātmanāanādabrahma tad-ānandam advitīyam upāsmahe //1// nādopāsanayā devā brahmā viṣnu maheśvarāh/bhavanty upāsitā nūnaì yasmād ete tadātmakāh //2//.

3 Sañgìta Ratnākara of Sārngadeva .Vol. 1.1.1. Shringy, trans., p. 1. vande nāda-tanuṁ tam uddhura-jagad gìtam mude śañkaram. 
Sañgìta Ratnākara of Śārngadeva. Vol. 1. 2.1-2. Shringy, trans., pp. 21-23. gītaì nādātmakaì vādyaì nāda-vyaktyā prakāśyate //1// tad-dvayānugataì nṛttam nādādhīnam atas trayam//nādena vyajyate varnah padaì varnāt padād vacah/vacaso vyavahāro 'yaì nādādhīnam ato jagat $/ / 2 / /$.

5 Sangīta Ratnākara of Śārngadeva. Vol. 1.1.3. Shringy, trans., p. 23. āhato 'nāhataś ceti dvidhā nādo nigadyate/so 'yami prakāśate piṇ̂̉e tasmāt pinḑo 'bhidhīyate //3//.

\section{References}

Beck, Guy L. 1993. Sonic Theology: Hinduism and Sacred Sound. Columbia: University of South Carolina Press.

Beck, Guy L. 2016. Wisdom of the Khayal Song. Kolkata: Bihaan Music. 2 Compact Discs.

Beck, Guy L. 2019. Sacred Music and Hindu Religious Experience: From Ancient Roots to the Modern Classical Tradition. Religions 10: 85. [CrossRef]

Beck, Guy L. 2021. Music. In The Wiley Blackwell Companion to the Study of Religion, 2nd ed. Edited by Robert A. Segal and Nickolas P. Roubekas. West Sussex: John Wiley \& Sons, Ltd., pp. 335-47.

Bhatkhande, Vishnu Narayan. 1974. Kramika-Pustaka-Mālikā. Edited by L. N. Garg. Hathras: Sangit Karyalaya, vols. 1-6. First published 1963.

Edgar, William. 1986. Taking Note of Music. London: SPCK.

Fiorenza, Francis Schussler, and Gordon D. Kaufman. 1998. God. In Critical Terms for Religious Studies. Edited by Mark C. Taylor. Chicago: University of Chicago Press, pp. 136-59.

Gelineau, Joseph. 1989. The Path of Music. In Music and the Experience of God. Edited by Mary Collins, David Power and Mellonee Burnim. Edinburgh: T \& T Clark, pp. 135-47.

Gerety, Finnian McKean Moore. 2015. This Whole World Is OM: Song, Soteriology, and the Emergence of the Sacred Syllable. Ph.D. dissertation, Harvard University, Cambridge, MA, USA.

Godwin, Joscelyn. 1987. Harmonies of Heaven and Earth: The Spiritual Dimension of Music from Antiquity to the Avant-Garde. Rochester: Inner Traditions.

Irwin, Joyce L. 1993. Neither Voice Nor Heart Alone: German Lutheran Theology of Music in the Age of the Baroque. Eugene: Wipf \& Stock.

Leaver, Robin A. 2017. Luther's Liturgical Music: Principles and Implications. Minneapolis: Fortress Press.

Meyer-Baer, Kathi. 1970. Music of the Spheres and the Dance of Death: Studies in Musical Iconology. Princeton: Princeton University Press.

Miner, Allyn, ed. 1998. Allyn Miner, trans. Sangītopanișat-Sāroddharah (A Fourteenth-Century Text on Music from Western India) Composed by Vacanācārya-Śrī Sudhakalaśa. New Delhi: Indira Gandhi National Centre for the Arts and Delhi, Motilal Banarsidass.

Mutatkar, Sumati. 2001. Shrikrishna Narayan Ratanjankar 'Sujan': A Many-splendoured Genius. New Delhi: Roli Books.

Otto, Rudolf. 1958. The Idea of the Holy: An Inquiry into the Non-Rational Factor in the Idea of the Divine and Its Relation to the Rational. New York: Oxford University Press, (1917 German, 1923 English).

Patvardhan, Vinayak N. 1970. Rāga-Vijūāna. Poona: Timalepar, vols. 1-7. First published 1960.

Pike, Alfred John. 1953. A Theology of Music. Ph.D dissertation, Philadelphia Conservatory of Music, Philadelphia, PA, USA.

Portnoy, Julius. 1954. The Philosopher and Music: A Historical Outline. New York: The Humanities Press.

Quasten, Johannes. 1983. Music \& Worship in Pagan \& Christian Antiquity. Washington, DC: National Association of Pastoral Musicians.

Adya Rangacharya. 2003, The Nātya-Śāstra: English Translation with Critical Notes. New Delhi: Munshiram Manoharlal.

Robertson, Alec. 1950. Sacred Music. New York: Chanticleer Press.

Schneider, Marius. 1989. The Nature of Praise Song. In Cosmic Music: Musical Keys to the Interpretation of Reality. Edited by Joscelyn Godwin. Rochester: Inner Traditions, pp. 35-52.

Seel, Thomas Allen. 1995. A Theology of Music for Worship Derived from the Book of Revelation. Studies in Liturgical Musicology No. 3. Metuchen: The Scarecrow Press.

Sharma, Prem Lata, ed. 1992. Prem Lata Sharma, trans. Bṛhaddeśī of Śrī Matañga Muni. New Delhi: Indira Gandhi National Centre for the Arts.

Shringy, Ravindra Kumar, and Prem Lata Sharma, eds. 1978. Ravindra Kumar Shringy, and Prem Lata Sharma, transs. Sañgīta Ratnākara of Śārngadeva. New Delhi: Munshiram Manoharlal, vol. I.

Stoltzfus, Philip E. 2006. Theology as Performance: Music, Aesthetics and God in Modern Theology. New York and Edinburgh: T \& T Clark. Thite, Ganesh Umakant. 1997. Music in the Vedas: Its Magico-Religious Significance. Delhi: Sharada.

Viladesau, Richard. 2000. Theology and the Arts: Encountering God through Music, Art, and Rhetoric. Mahwah: Paulist Press.

Wainwright, Geoffrey. 1980. Doxology: The Praise of God in Worship, Doctrine and Life. A Systematic Theology. New York: Oxford University Press. 